\title{
Faunal survey of the coffee leaf miner, Leucoptera coffeella, parasitoids in Puerto Rico'
}

\author{
Fernando Gallardo-Covas ${ }^{2}$
}

\begin{abstract}
The coffee leaf miner (CLM), Leucoptera coffeella Guérin-Méneville, is the worst coffee pest in Puerto Rico. Damage by this insect can reduce yields up to $40 \%$. In Puerto Rico the use of chemical insecticides is the main control tactics while little attention has been given to the use of CLM natural enemies. Little is known about CLM endemic parasitoids. In an attempt to obtain more information about CLM parasiroids, a faunal survey throughout the coffee region of Puerto Rico was done in 1985 and 1986. In the 1985 survey the highest parasitism percentage (66.7) was obtained on the Bennazar farm at Bo. Yahuecas, Adjuntas, followed by Hacienda Balear at Bo. Guayo, Adjuntas, and Roman's farm at Bo. Espino Ceiba, Lares, with $\mathbf{4 2 . 9}$ and $36.4 \%$ of parasitism, respectively. In the 1986 survey the highest parasitism percentage $(54.0 \%)$ was obtained at Bo. Toro Negro, Villalba followed by Bo. Carmelita, Ponce and Bo. Coliores, Juana Díaz, with 47.8 and $47.0 \%$ of parasitism, respectively. No correlation was obfained between elevation and parasitism percentage. Five Eulophidae, Cirrospiloideus sp., Zagrammosoma sp., Horismenus sp., Achrysonocharoides sp., Chrysonoromyia sp., and a Braconid, Mirax insularis Musesebeck, were collected. The Braconid parasitoid, Mirax insularis, imported from Guadeloupe, West Indies, to Puerto Rico in 1937 and liberated at Lares and Quebradillas, was collected by the author over the entire coffee areas. The highest percentage of parasitism was recorded for Achrysonocharoides sp., $(33.1 \%)$ followed by $M$. insularis $(32.4 \%)$. The Eulophidae complex represents $67.6 \%$ of the total parasitoid population. The total percentage of CLM parasitism for the coffee area surveyed was $23.5 \%$ for 1985 and $19.5 \%$ for 1986 .
\end{abstract}

\section{INTRODUCTION}

The coffee leaf miner (CLM) Leucoptera coffeella Guérin-Méneville, is the main insect pest of coffee in Puerto Rico. The caterpillar of this silvery moth penetrates the leaf and feeds on the mesophyll for about 3 weeks. Large brown spots on the leaves are the typical symptoms of infestation by this pest. This damage reduces leaf photosynthetic activity by $50 \%$ and can cause 70 and $60 \%$ weight loss of stalks and roots, respectively (3). Nantes and Parra (6) reported in Brazil a 21.6\% loss in coffee yield when $46.24 \%$ of the coffee plant leaves were damaged by the CLM.

This pest was reported by Guérin-Méneville and Perrottet on coffee in Guadeloupe and Martinique (5) as Elaschista and later referred to by

'Manuscript submitted to Editorial Board 6 May 1987.

${ }^{2}$ Assistant Entomologist, Crop Protection Department, Agricultural Experiment Station, Adjuntas Substation, HC-01, Box 4508, Adjuntas, P. R. 00601-9717. 
Station (11) as Cemiostoma. Because of a misidentification, the common Leucoptera found in Africa was referred to as $L$. coffeella in nearly all the literature up to 1958, when Bradley (2) solved the confusion by distinguishing it from $L$. meyricki.

L. coffeella occurs throughout the Neotropical region in almost every country in which coffee is grown. It was probably brought to Puerto Rico with the first coffee plants. The first record for Puerto Rico was reported by 0 . W. Barret in 1903 (1). Since then, this insect has been studied by Wolcott (13), Van Zwaluwenburg (12), Seín $(9,10)$ and later by Pérez (8).

In Puerto Rico disuifoton $15 \mathrm{G}$ (Disyston) and carbofuran $10 \mathrm{G}$ (Furadan) are the main insecticides used against CLM. In 1985, Puerto Rican coffee growers spent around $\$ 1$ million on the chemical control of this pest (4). Because of the topographic and climatic conditions of the coffee region of Puerto Rico it is difficult to obtain a good control of CLM with chemicals. In addition, granular insecticides can penetrate and contaminate streams. Therefore, other control tactics with less damage to the environment such as biological control should be evaluated.

Biological control of the CLM includes the use of parasites and predators (7). Wolcott (13) reported 10 parasitoids reared from the CLM larvae that occurred in shaded coffee groves in Puerto Rico. These are arranged in order of aioundance: Closterocerus leucopus Ashmead; Chrysocharis lividus Ashmead; Horismenus cupreus Ashmead; Zagrammosoma sp. nov.; Closterocerus sp. near cinctipennis Ashmead; Cirrispiloideus sp. nov.; Darastenus sp. near fullawayi Crawford; Tetrastichus sp. nov.; Telenomus sp.; and Microbracon sp.

Seín $(9,10)$ introduced $M$. insularis form Guadeloupe to control the CLM. Recovery tests indicated that it became permanently established although the incidence was very low. In Guadeloupe this parasitoid destroys from 65 to $85 \%$ of the CLM caterpillars.

A correlation between climatic conditions (humidity and temperature) and CLM parasitoid population was reported by Wolcott (13) and Seín (9). They observed that near the coast and at elevations no greater than 50 to 200 meters above sea level some of these minute parasitoids were at times reasonably abundant, but at higher elevations (200 to $900 \mathrm{MSL}$ ), where most of the coffee is produced in Puerto Rico, parasitoids were far from numerous and usually were so scarce that all species combined rarely destroy more than a tenth of the CLM population. Climatic and cultural differences between the present coffee groves (sunlight) and the past coffee groves (shaded) probably would increase the CLM parasitoid population.

The research reported here was initiated to offer biological control as an alternative for CLM control. A faunal survey of the CLM parasitoids present on the island is the first step in such a project. The survey was done in 1985-1986, in an effort to obtain useful information of a biological control progxam of the CLM in Puerto Rico. 


\section{MATERIALS AND ME'THODS}

A field survey of the CLM parasitoids was conducted in 1985-1986 on sunlight coffee groves of Puerto Rico. Different municipalities were surveyed once during the year (tables 1 and 2). The survey was conducted from May to August, in accordance with CLM population peak. One hundred mined leaves were collected at random per survey station and brought to the laboratory. Each mined leave was cut in small pieces (each piece with a mine) and placed in a glass vial stoppered with a cotton ball. Vials were arranged in trays and held under laboratory conditions for about 1 month or until the parasitoid or the CLM emerge. The number of CLM and parasitoids that emerged were recorded. Elevation readings were obtained with a Swiss-Thommen ${ }^{3}$ altimeter. Collected parasitoids were identified by specialists of the USDA Biosystematics and Beneficial Insects Institute at Beltsville, Maryland, U.S.A.

TABLE 1.-Faunal survey of the coffee leafminer, L. coffeella, parasitoids in Puerto Rico, 1985

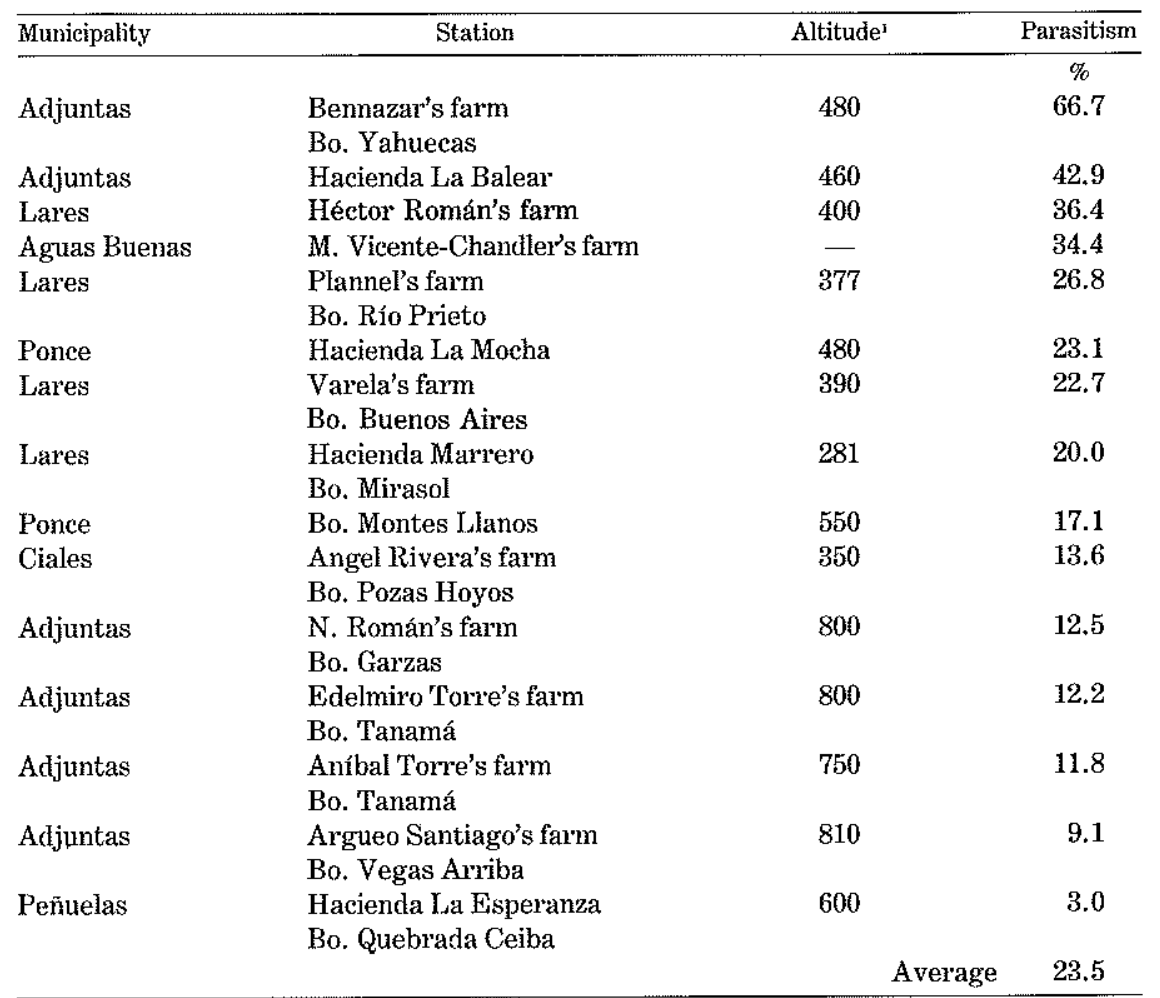

${ }^{1}$ Meters above sea level.

sTrade names in this publication are used only to provide specific information. Mention of a trade name does not constitute a warranty of equipment or materials by the Agricultural Experiment Station of the University of Puerto Rico, nor is this mention a statement of preference over other equipment or materials. 


\section{RESULTS AND DISCUSSION}

Table 1 summarizes data for the 1985 parasitoids survey. The highest parasitism percentage $(66.7 \%)$ was recorded at the Bennazar farm, Bo. Yahuecas, Adjuntas, followed by that at Hacienda Balear at Bo. Guayo, Adjuntas, and Roman's farm at Bo. Espino Ceiba, Lares, with 42.9 and $36.4 \%$, respectively. The lowest parasitization percentage $(3.0 \%)$ was obtained in Hacienda La Esperanza at Bo. Quebrada Ceiba, Peñuelas.

Table 2 summarizes data for the 1986 survey. The highest parasitism percentage $(54.0 \%)$ was obtained in Hacienda Los Figueroa at Bo. Toro Negro, Villalba, followed by that of Ayala's farm at Bo. Carmelita, Ponce; and B. Collores, Juana Díaz, with 47.8 and $47.0 \%$, respectively. The lowest parasitism percentage (2.8\%) was obtained at.Finca Alzamora, RUM, Mayagüez.

TABLE 2.-Faunal survey of the coffee leafminer, L. coffeella, parasitoids in Puerto Rico, 1986

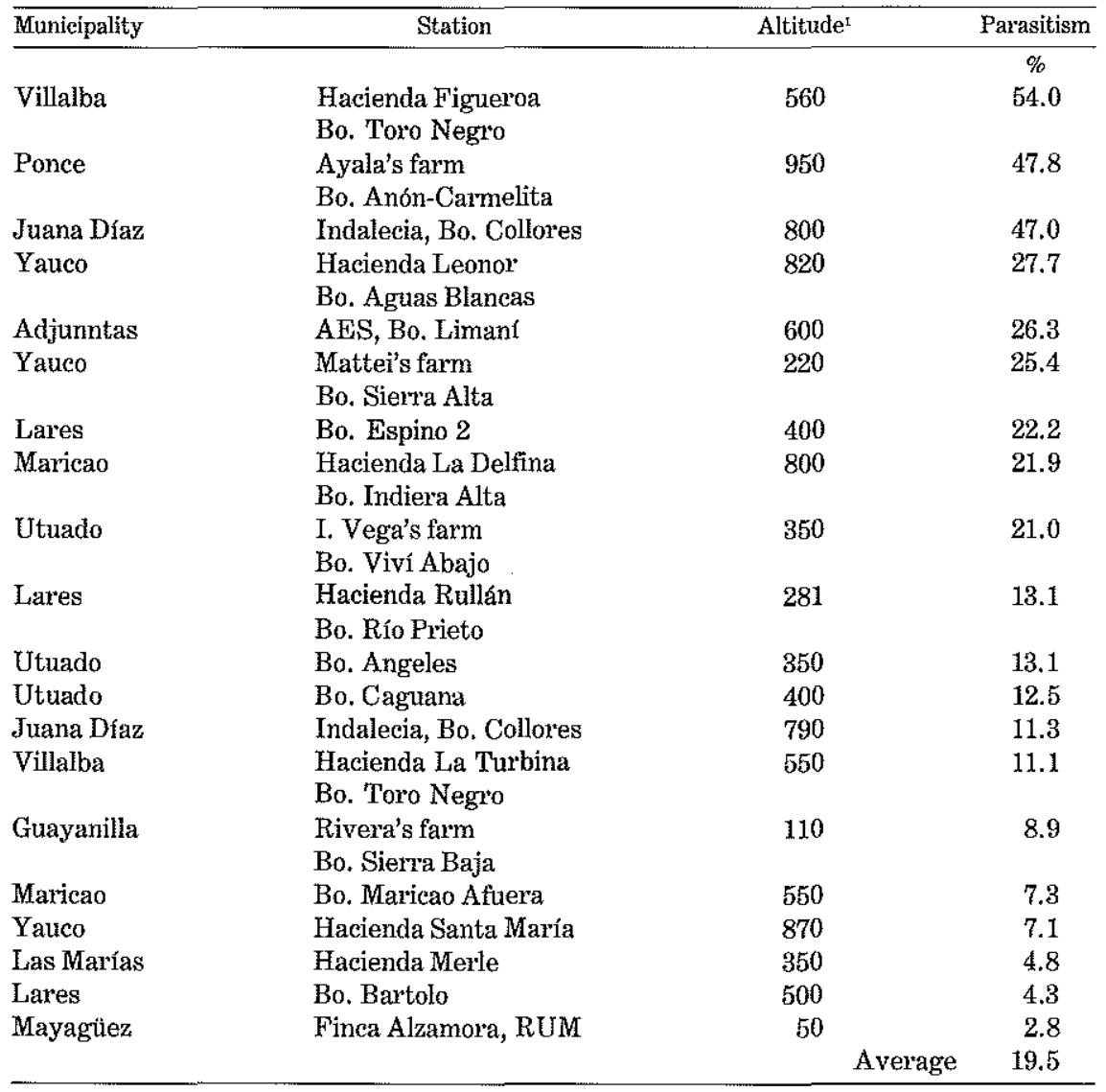

\footnotetext{
${ }^{1}$ Meters above sea level.
} 
Five eulophid parasitoids were collected and sent to M. E. Schauff of BBII-USDA who identified the specimens as Cirrospiloideus sp., Zagrammosoma sp., Achrysocharoides sp., Horismenus sp., Chrysonotomyia sp.

A Braconidae wasp, Mirax insularis Muesebeck, was determined by P. M. Marsh of BBII-USDA. This parasitoid was introduced from Guadeloupe to Puerto Rico in 1937 (9). The parasitoid was released on shaded coffee groves at Lares and Quebradillas. In 1938 it was recovered at Lares and at Quebradillas up to November. Small quantities of $M$. insularis were collected that year (1938); Seín attributed that paucity to the seasonal scarcity of its host. After that date no more recoveries were made until May 1986, when seven $M$. insularis were collected in Lares.

$M$. insularis was collected in 1986 from the following coffee areas: Adjuntas, Juana Díaz (Bo. Collores), Lares, Las Marías, Maricao, Ponce, Utuado, Villalba and Yauco (fig. 1); thus the introduced parasitoid has become established throughout the entire coffee region of Puerto Rico.

The composition of the parasitoid population (expressed as total parasitism percentage) is summarized in figure 2 . The highest percentage (33.1\%) was obtained for Achrysocharoides sp. followed by $M$. insularis (32.4\%). The Eulophidae complex represents $67.6 \%$ of the total parasitoid population.

Table 3 presents the total percentage of coffee leafminer parasitism by each parasitoid for the coffee area surveyed (fig. 3). The percentage

A T L A N T I C O C E A N

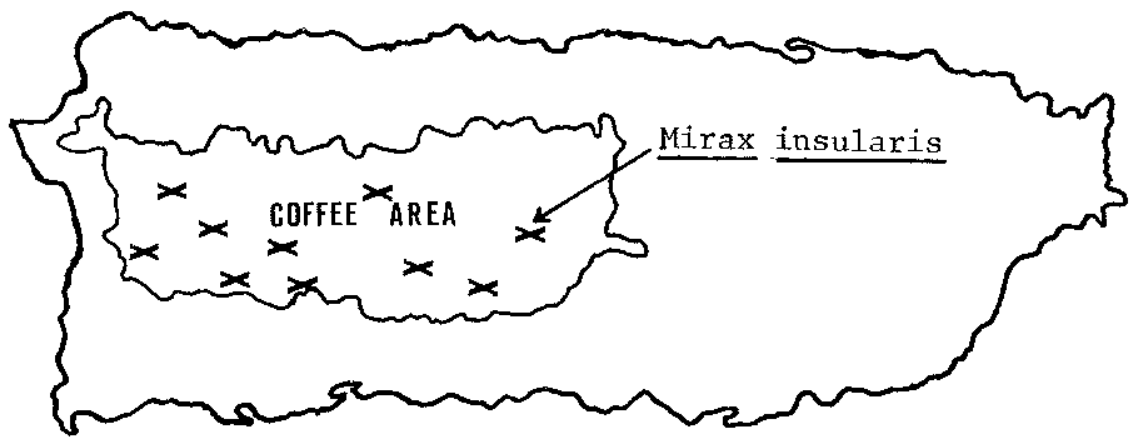

C A R I B B E A N $\quad$ S E A

FIG. 1.-Distribution of Mirax insularis (Hymenoptera: Braconidae) throughout the coffee area of Puerto Rico. 


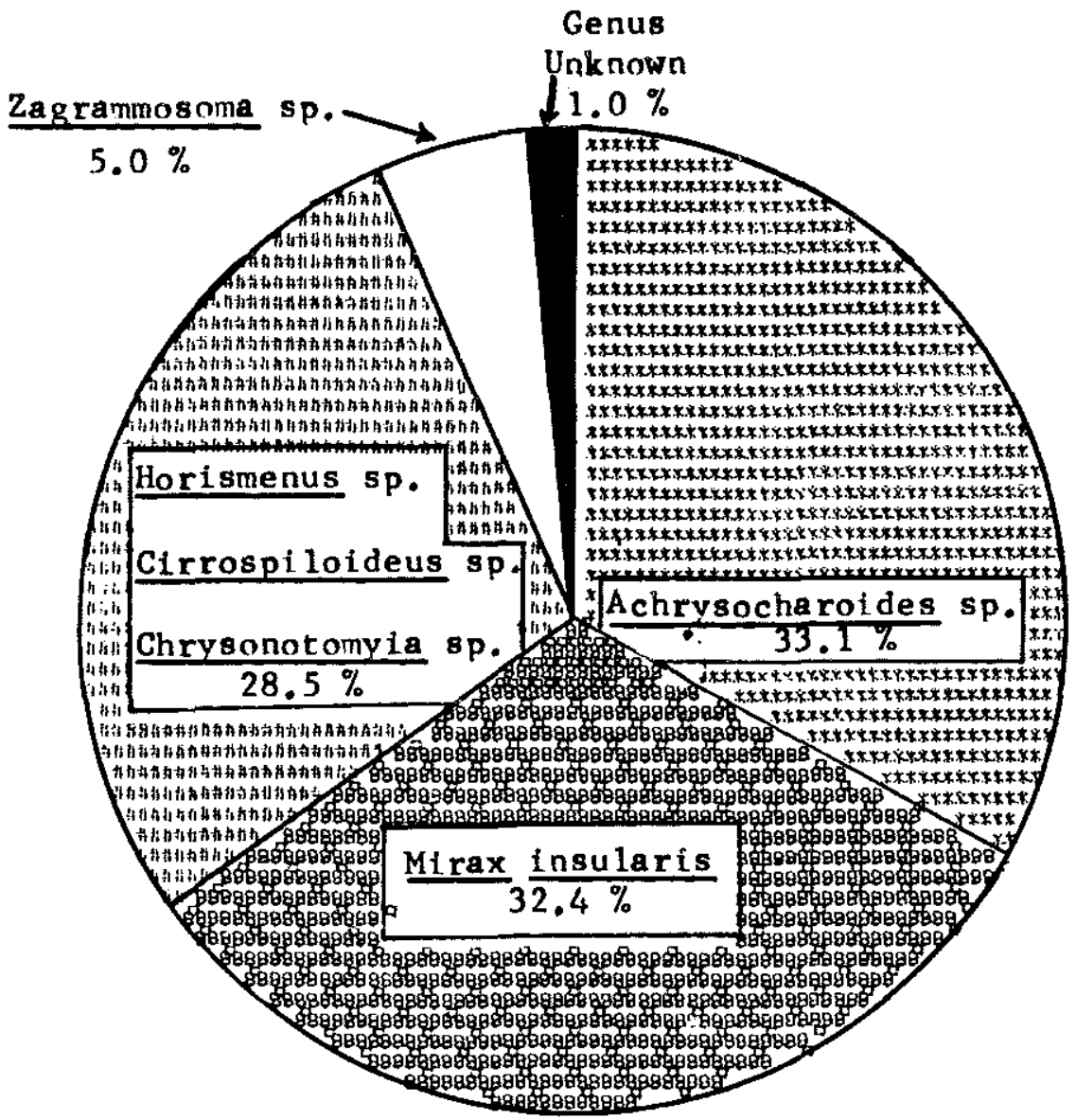

FIG. 2.-Percentage of parasitoid populations of the coffee leafminer, L. coffeella, in Puerto Rico, 1986.

of parasitism by all parasitoids combined in Puerto Rico was $23.5 \%$ in 1985 and 19.5\% in 1986; it is evident that parasitoids are acting on the CLM population but an increase of parasitism percentage is needed.

No correlation was obtained between elevation and parasitism. This observation is completely different from that pointed out by Wolcott (13) and Seín (9), who reported a correlation between these two parameters: parasitism is higher at lower elevations. Comparisons between our observations and Seín-Wolcott's observations are difficult because of the difference in coffee cultivation from 1938-40 and current cultivation. At present coffee is grown under sunlight. Climatic conditions in sunlight groves, such as temperature and relative humidity, are different from those of shade coffee. CLM parasitoid populations increased at higher elevations. 
TABI.E 3.-Parasitism percentage of the coffee leafminer L. coffeella, in Puerto Rico, $1985-86$

\begin{tabular}{lcrr}
\hline & & \multicolumn{2}{c}{ Survey } \\
\cline { 3 - 4 } Parasitoids & 1985 & & 1986 \\
\hline Braconidae & 7.1 & Percentage & 5.9 \\
$\quad$ Mirax insularis & & & \\
Eulophidae & & & 6.0 \\
$\quad$ Achrysocharoides sp. & 7.2 & 1.4 \\
Zagrammosoma sp. & 1.7 & 5.4 \\
Cimospiloideus sp. & & \\
Horismenus sp. & 6.5 & .8 \\
$\quad$ Chrysonotomyia sp. & & 1.0 & 19.5 \\
Genus unknown & Total & 23.5 & \\
\end{tabular}

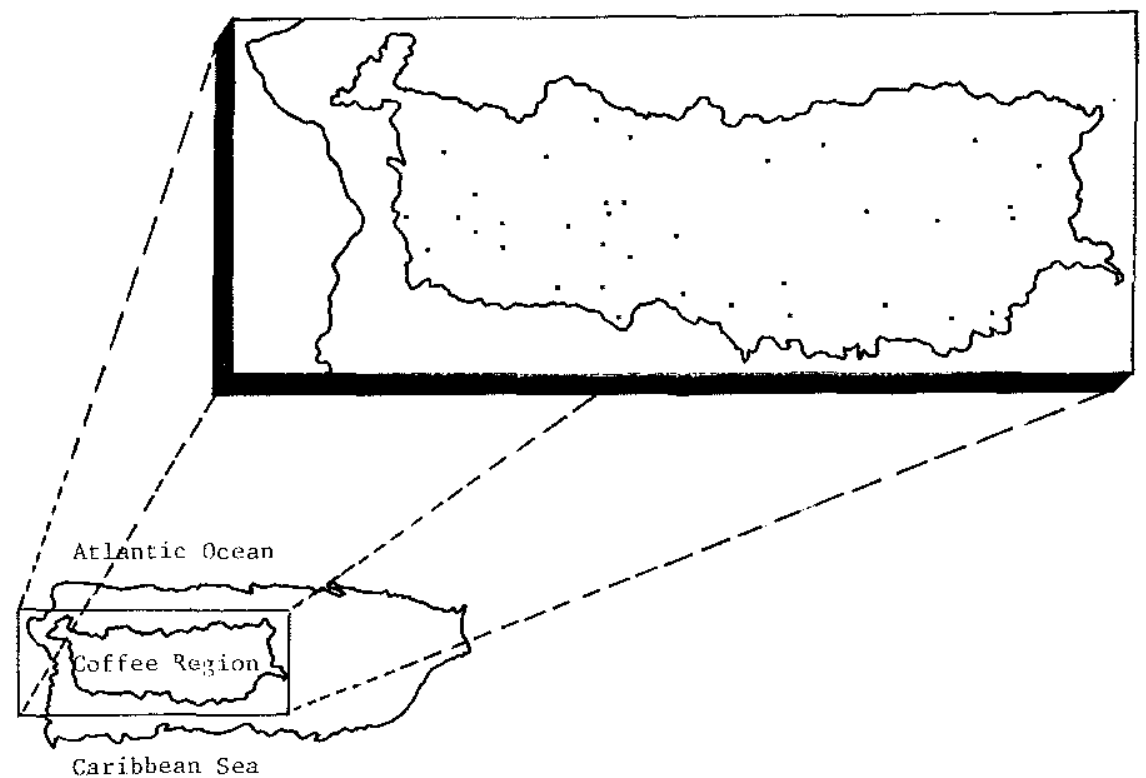

FIG. 3.-Coffee region surveyed for the coffee leafminer, $L$. coffeella parasitoids, 198586. 
Correlations that need additional research are beyond the scope of this study.

\section{RESUMEN}

Censo de los parasitoides del minador del cafeto, Leucoptera coiffeella, en Puerto Rico

El minador de las hojas del cafeto, Leucoptera coffeella GuérinMéneville, es el principal insecto que ataca el café en Puerto Rico. Sus larvas penetran el mesófilo donde se alimentan por 3 semanas. Este daño puede ocasionar pérdidas de hasta un $\mathbf{4 0 \%}$ en la producción. Durante las últimas décadas el minador se ha estado combatiendo con aplicaciones anuales de Disyston 15 G, un insecticida sistémico que se aplica sobre el suelo cerca de las raíces del arbusto. Es necesario establecer otras alternativas de combate que disminuyan el riesgo a la salud y al ambiente. El uso de agentes naturales (control biológico) como los parasitoides podría ser la alternativa segura para el combate de esta plaga.

El primer paso de un programa de control biológico es comprobar la presencia de paraśitos y depredadores endémicos y su distribución en el lugar - comarca estudiados. Con este propósito se hizo una inspección de dos años (1985 y 86) en un amplio sector de la región cafetalera de Puerto Rico en busca de los parasitoides del minador de las hojas del cafeto.

Los resultados obtenidos en 1985 indican que el mayor porcentaje de parasitismo $(66.7 \%)$ se observó en la finca Bennazar en Adjuntas a una altitud de $\mathbf{4 8 0} \mathrm{m}$. snm, seguido por la Hacienda Balear en Adjuntas a 460, y por la finca Román en Lares a $\mathbf{4 0 0} \mathrm{m}$. con $\mathbf{4 2 . 8}$ y $\mathbf{3 6 . 4 \%}$ de parasitismo, respectivamente.

En la inspección de 1986 el mayor procentaje de parasitismo $(54.0 \%)$ se obtuvo en Villalba (Bo. Toro Negro) a 560 m., seguido por Ponce (Bo. Carmelita) a 950 m. y Juana Díaz (Bo. Collores) a 800 m., con 47.8 y $47.0 \%$ de parasitismo, respectivamente.

No se pudo demosirar que haya correlación entre la altitud y el porcentaje de parasitismo. Se identificaron cinco eulófidos: Horismenus sp., Cirrospiloideus sp., Zagnammosoma sp., Achrysocharoides sp., y Chrysonotomyia sp. También se recolectó el parasitoide importado de Guadalupe en 1937, Mirax insularis. Este parasitoide se encontró distribuido por toda la región cafetalera de la isla. El porcentaje de parasitismo más alto observado fue de Achrysocharoides sp. (33.1\%), seguido por $M$. insularis (32.4\%). El complejo de parasitoides del minador de las hojas del cafeto se encontró actuando en un 23.5 y $19.5 \%$ en 1985 y 1986 , respectivamente, sobre el total de la población del minador.

\section{LITERATURE CITED}

1. Barret, O. W., 1904. Ann. Report P. R. Agric. Exp. Stn., 1903. pp. 429-50, Washington, D.C.

2. Bradley, J. D., 1958. Taxonomic notes on Leucoptera meyricki Chesquiére and Leucoptera coffeella Guérin Méneville Bull. Ent. Res. 48: 417-19, London.

3. Cibes, H. R. and M. Pérez, 1958. Minador de la hoja disminuye en grado consiclerable el vigor de los cafetos. El café de El Salvador, 28: 325-26. 
4. Deynes Soto, R., 1985. Informe económico de la empresa de café. Reunión de Empresa del Café. Marzo 18, 1985. U.P.R. Recinto de Mayagüez, P. R.

5. Guérin-Méneville and Perrottet, 1842. Memoir sur un insecte et un champignon que revagent les caféiers aux Antilles. Min. Marine. 1-32, 2 pl. Paris.

6. Nantes, J. R. P. y J. R. P. Parra, 1977. Avalição de danos eausados por Perileucoptera coffeella (Guérin-Méneville, 1842) (Lepitoptera: Lyonetidae), em três variedades de café (Coffea spp.). Solo 69: 26-9.

7. Parra, J. R. P., W. Gonçalves e A. R. Marconato, 1977. Parásitos e predadores do bicho-mineiro Perileucoptera coffeella en São Paulo. Ann. Soc. Entom. Brasil 6 (1): 138-43.

8. Pérez Escolar, M. E., 1962. Recomendaciones para controlar el minador del café con el insecticida sistémico Di-syston. Publ. Misc. 42, Esta. Exp. Agric. Univ. P. R.

9. Sein, F., 1940. Ann. Rep. P. R. Agric. Exp. Stn. 1938-39. pp. 50-52, Washington, D.C.

10. —, 1941-42. Ann. Rep. P. R. Agric. Exp. Stn. 1941-42. pp. 20, Washington, D.C.

11. Station, H. T., 1961. Entomology Weekly Intelling. X. pp. 110-11.

12. Van Zwaluwenburg, R. H., 1917. Insects affecting coffee in Puerto Rico. J. Econ. Ent. 109: 513-17. Concord, N. H.

13. Wolcott, G. N., 1947. A quintessence of sensitivity: The coffee leafminer J. Agric. Univ. P. R. 31 (3): 215-19. 